\title{
СУБЪЕКТЫ ПРАВООТНОШЕНИЙ, СВЯЗАННЫХ С ДОГОВОРОМ МЕЖДУНАРОДНОГО ЗАЙМА
}

\begin{abstract}
Аннотация: В статье проанализированы субъекты правоотномений, связанных с договором международного займа. Приведены особенности правового статуса и характер участия в указанных отномениях физических лии, иностранных коммерческих банков, международных банков, государств, коммерческих организаций. Особое внимание уделено проблемам, возникающим в российской судебной практике в связи с участием иностранных банков в международных заёмных отношениях на территории Российской Федерации, а также особенностям участия международных банков и государств в указанных отношениях. Отдельное внимание уделено роли третьих лии в правоотношениях, связанных с договром международного займа. В статье использован системный и комплексный метод, а в части описания субъектов - метод анализа. В статье анализируются различные источники какмеждународного, так и национального права. В зависимости от особенностей правового статуса автор выделяет пять видов субъектов правоотношений, связанных с договором международного займа: физические лииа, иностранные коммерческие банки, международные банки, государства и коммерческие организачии. Автор обнаруживает пробель в российском законодательстве, связанные с правовым статусом иностранных банков, а также ошибочные подходы российских судов в делах с участием указанных лиц. Детально описаны особенности участия международных банков и государств в международных заёмных правоотнотениях.

Abstract: The article provides analysis of subjects of legal relations regarding the international loan contract. The author discusses specific features of legal status and character of participation of natural persons, foreign commercial banks, international banks, states and commercial organizations in these relations. Special attention is paid to the problems arising in the Russian judicial practice regarding participation of foreign banks in the international loan relations in the territory of the Russian Federation, as well as to the specific features of participation of international banks and states in these relations. Special attention is also paid to the role of third parties in the legal relations regarding international loan contracts. The article involves systemic and complex methods, and the method of analysis is applied in part of description of subjects. The article provides analysis of various sources of both international and national law. Depending on specific features of their legal status the author singles out five types of subjects of legal relations regarding international loan contract: natural persons, foreign commercial banks, international banks, states, commercial organizations. The author reveals blanks in the Russian legislation regarding legal status of foreign banks, as well as mistaken approaches of the Russian courts in some cases involving these persons. The article includes detailed description of specific features of participation of international banks and states in the international loan relations.
\end{abstract}

Ключевые слова: Договор займа, международные банки, иностранные банки, государства, коммерческие организачии, трансграничные отношения, деривативы, экспортное кредитование, государственные гарантии, государственный иммунитет.

Keywords: Loan contract, international banks, foreign banks, states, commercial organizations, transborder relations, derivatives, export crediting, state guarantees, state immunity.

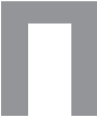
равоотношение - это урегулированное правом отношение одного лица к другим лицам'. Элементами всякого правоотношения являются правомочие, обязанность (иными словами, содержаниеправоотношения), субъект, обладающий правом, и объект права.

\footnotetext{
${ }^{1}$ Трубеикой Е.Н. Энциклопедия права. М.: Юридический институт (Санкт-Петербург), 1998. С. 123.
}

Предметом настоящей статьи являются правоотношения, связанные с договором международного займа. В коммерческой действительности международные заёмные отношения не ограничиваются исключительно одним договором и одним правоотношением: договор международного займа порождает целую цепь связанных с ним правоотношений, как обязательственных, так и вещных, как частных, так и публичных. К примеру, 
DOI: $10.7256 / 1811-9018.2014 .8 .12742$

При цитировании этой статьи сноска на dоі обязательна

\section{Право и политика $8(176) \cdot 2014$}

если заём представляет для заёмщика или займодавца крупную сделку, он подлежит одобрению соответствующим органом управления, например, общим собранием участников, и в таком случае возникают корпоративные отношения ${ }^{2}$. С другой стороны, для того чтобы получить заём, российскому заёмщику - небанковской организации необходимо оформить соответствующий паспорт сделки, и в данном случае заёмщик становится участником правоотношений публичного характера 3 . Тем не менее, несмотря на множество различных отношений, возникающих в связи с выдачей международного займа, отдельным блоком можно выделить отношения обязательственные: не только из договора займа, но из связанных с ним сделок-главным образом, обеспечительных.

Субъектом правоотношений, связанных с договором международного займа, может быть любое дееспособное лицо - физическое или юридическое лицо, государство или международная организация. Правовой статус данных лиц, однако, будет различен.

\section{Физические лица}

Количество правоотношений с участием физических лиц в правоотношениях международного займа крайне мало ${ }^{4}$. Это объясняется множеством причин: как особенностью правового статуса физических лиц (их личного статута и связанных с ним дееспособностью, имущественным положением и несостоятельностью), так и спецификой собственно трансграничных заёмных отношений (большими суммами займа, издержками, языковым и территориальным барьером и др.).

Тем не менее, участие физических лиц в правоотношениях из договоров международного займа не исключено там, где указанные лица являются

\footnotetext{
${ }^{2}$ Так, в соответствии со ст. 46 Федерального закона РФ от 8 февраля 1998 г. № 14-Ф3 «Об обществах с ограниченной ответственностью», заём, среди прочих сделок, отнесен к категории сделок, которые могут при определенных обстоятельствах считаться крупными как для заёмщика, так и для займодавца.

${ }^{3}$ Ст. 20 Федерального закона РФ от 10 декабря 2003 г. № 173-Ф3 «О валютном регулировании и валютном контроле»; Инструкция Центрального Банка РФ от 4 июня 2012 г. № 138-И «О порядке представления резидентами и нерезидентами уполномоченным банкам документов и информации, связанных с проведением валютных операций, порядке оформления паспортов сделок, а также порядке учета уполномоченными банками валютных операций и контроля за их проведением».

${ }^{4}$ Несмотря на это, в российском бюджетном законодательстве, например, предусмотрена возможность участие иностранных физических лиц в качестве займодавцев в заёмных отношениях с Российской Федерацией (ст. 97 БК РФ).
}

основными акционерами (участниками) заёмщика или третьих лиц, а также предоставляют залог, поручительство или другое обеспечение, и там, где такие физические лица выступают конечным бенефициаром стороны в правоотношении. В последнем случае физические лица, скорее всего, будут участвовать не столько в обязательственных правоотношениях, сколько в корпоративных; не исключено также участие физических лиц в соглашении о правах инвесторов и в опционном договоре, если подобные отношения предусмотрены в структуре заёмной сделки. Следует отметить, что физические лица, чаще всего, выпадают из поля международно-правового регулирования. Так, например, Принципы УНИДРУА о действии условий ликвидационного неттинга не касаются отношений с участием потребителей ${ }^{5}$ при разработке указанных Принципов участники решили пойти по пути, принятом в Венской конвенции о договорах международной купли-продажи 1980 года.

\section{Иностранные банки}

Кредиторами в правоотношениях, связанных с договором международного займа, выступают, как правило, крупные международные банки организации обладают не только необходимыми заёмными средствами, но также и целой сетью дочерних обществ, которые дают возможность вступать в правоотношения (и участвовать в их развитии) одновременно в нескольких юрисдикциях. Особое значение следует уделять личному статуту банка, поскольку он будет определять дееспособность банка заключать международный договор займа, непосредственно влияющую на его действительность.

В соответствии со ст. 1202 ГК РФ под личным статутом юридического лица понимается право страны, где учреждено юридическое лицо - один из основных принципов определения личного статута в большинстве развитых стран. В некоторых странах под личным статутом понимается право страны, являющейся основным местом деятельности данного лица. Личным статутом, в частности, определяется содержание правоспособности юридического лица, а также порядок приобретения юридическим лицом гражданских прав и принятия на себя гражданских обязанностей.

\footnotetext{
${ }^{5}$ Principle 3 (1) of Principles on the operation of close-out netting provisions // International Institute for the Unification of Private Law (UNIDROIT). Rome, 2013.

${ }^{6}$ Путилин В.И. Технологии международного синдицированного кредитования // Международные банковские операции. 2012. № 4.
} 
В России вопрос о том, могут ли иностранные кредитные организации, не имеющие лицензии Центрального банка РФ (далее - ЦБ РФ) на осуществление банковской деятельности на территории РФ, предоставлять кредиты российским заёмщикам напрямую, не решен в праве РФ. Это объясняется особенностью российского гражданского законодательства, которое содержит специальные нормы, посвященные кредитному договору. Ст. 819 ГК РФ предусматривает, что субъектом кредитного договора может выступать только кредитная организация. В соответствии со ст. 1 Федерального закона от 2 декабря 1990 № 395-1 «О банках и банковской деятельности» (далее - «Закон о банках») кредитной организацией признается юридическое лицо, которое для извлечения прибыли как основной цели своей деятельности на основании специального разрешения (лицензии) ЦБ РФ имеет право осуществлять банковские операции, предусмотренные Законом о банках. Кредитная организация образуется на основе любой формы собственности как хозяйственное общество. Иностранный банк определяется как банк, признанный таковым по законодательству государства, на территории которого он зарегистрирован.

При анализе указанных норм возникает вопрос: может ли иностранный банк, не имея лицензии ЦБ РФ, выступать кредитором в кредитном договоре? На данный вопрос можно было бы дать положительный ответ, приведя в обоснование норму, закрепленную в ст. 1202 ГК РФ. Более того, российскими судами не оспаривается правомерность вступления в кредитные отношения иностранных банков 7 . Тем не менее, в практике некоторых региональных судов встречаются решения, прямо противоположные общепринятому подходу8.

Так, в 2013 г. апелляционный арбитражный суд Томска, пересматривая дело с участием казахстанского банка, касающееся отношений из договора об открытии кредитной линии, а также обеспечивающей его ипотеки, поддержал вывод суда первой инстанции о том, что заключенный договор является ничтожным, как не соответствующий требованиям российского законодательства. Суд аргументировал свою позицию тем, что казахстанский банк образован в соответствии с законодательством Республики Казахстан, не имеет на территории РФ филиалов или

\footnotetext{
${ }^{7}$ См.: Постановление Федерального арбитражного суда Московского округа от 06 июля 2004 г. по делу № КГ-А40/3926-04.

${ }^{8}$ См.: Постановление Седьмого арбитражного апелляционного суда от 13 августа 2013 г. по делу № А45-29905/2012.
}

представительств, а также не обладает выданной Банком России в установленном порядке лицензией на осуществление банковских операций.

Суд специально отметил, что иностранные банки могут осуществлять банковскую деятельность на территории РФ только в случае учреждения кредитной организации с иностранными инвестициями или открытия своего филиала на территории РФ в соответствии с законодательством РФ. При этом суд подчеркнул, что основанием признания кредитного договора ничтожным является не отсутствие лицензии (совершение сделки за пределами правоспособности), а «абсолютная юридическая невозможность признания казахстанского банка банком или иной кредитной организацией в соответствии с действующим законодательством РФ». Таким образом, позиция суда заключалась в том, что гражданским законодательством не предусмотрено заключение кредитных договоров с участием иностранных банков при том условии, что последние не имеют присутствия на территории РФ в форме дочерней кредитной организации или филиала.

В ответ на заявление ответчика о том, что стороны заключили не кредитный договор, а договор займа, суд, суд, соглашаясь с доводами истца, указал, что заключенный между сторонами договор обладал признаками, которые не позволяют отнести заключённый договор к договору займа. К таким признакам суд отнес:

- $\quad$ наличие условия о предоставлении кредита отдельными траншами, что невозможно в договоре займа, поскольку он носит реальный характер и считается заключенным с момента предоставления денежных средств;

- наличие условия о возможности отказа кредитора в предоставлении очередной суммы транша, что подтверждает консенсуальную природу рассматриваемого договора (договор займа является реальной сделкой и считается заключенным с момента предоставления заёмных средств, а несоблюдение условий финансирования, в том числе в виде уменьшения обеспечения по займу, может явиться только основанием для досрочного востребования суммы займа, но не основанием отказа в предоставлении займа);

- наличие условий, свойственных исключительно отношениям, основанным на кредитном договоре: о взимании комиссионного вознаграждения за организацию финансирования, о проверке банком целевого использования кредита, описание предоставленного обеспечения, возможность изменения процентной ставки по кредиту. 
DOI: $10.7256 / 1811-9018.2014 .8 .12742$

При цитировании этой статьи сноска на dоі обязательна

\section{Право и политика $8(176) \cdot 2014$}

Следует отметить, что ранее А.А Кыров, в связи с неясностью законодательства в вопросах правоспособности иностранных банков на заключение кредитных договоров по российскому праву, выдвигал предложения по внесению определенных изменений в российское законодательство9. Автор предлагал внести изменения в ст. 1 Закона «О банках» с тем, чтобы более явно определить право иностранных банков осуществлять соответствующую деятельность без лицензии ЦБ РФ. В свою очередь, по мнению А.А. Кырова, иные иностранные юридические лица должны получить соответствующую лицензию.

Другой аспект проблемы участия иностранных банков в отношениях с российскими заёмщикам - организационно-правовая форма присутствия на российском рынке. В международной практике некоторые иностранные банки предпочитают предоставлять займы напрямую, без учреждения филиалов или представительств - такая практика обусловлена, главным образом, соображениями, связанными с оптимизацией налогообложения. На территории РФ иностранные банки могут учреждать дочерние организации или вступать в кредитные отношения с российскими лицами через свои филиалы и представительства ${ }^{10}$. Иностранные филиалы и представительства открываются с особого разрешения, выдаваемого ЦБ РФ ${ }^{11}$.

Тем не менее, несколько иной подход сложился в практике Европейского Союза. Так, в соответствии с позициями, изложенными в деле SAR Schotte GmbH v. Parfums Rothschield ${ }^{12}$, касающегося применения

\footnotetext{
${ }_{9}^{9}$ Кыров А.А. Правовые основания заключения кредитного договора с иностранным юридическим лицом // Судебно-арбитражная практика Московского региона. Вопросы правоприменения. 2008. № 5.

10 Любопытно в этой связи замечание специалистов Всемирного Банка о том, что чем рискованнее макроэкономическая ситуация в стране, в которой иностранный банк планирует осуществлять свою деятельность, тем больше вероятность того, что последний будет действовать через представительство или филиал. Cм.: E. Cerutti, G. Dell-Ariccia, M. Soledad Marinez Reia. How Banks Go Abroad: Branches or Subsidiaries? // Policy Research Working Papers. World Bank. 2005. P. 4. World Bank official website: $<$ http://elibrary.worldbank. org/doi/book/10.1596/1813-9450-3753>. В России по состоянию на 1 ноября 2013 г. кредитных организаций с иностранным участием в уставном капитале - 252, а филиалов банков-нерезидентов - 0 . Официальный сайт Банка России: <www.cbr.ru> .

${ }^{11}$ В настоящее время филиалы иностранных банков исключены из состава банковской системы России. Приказ Центрального банка РФ от 7 октября 1997 г. № 02-437 «О порядке открытия и деятельности в РФ представительств иностранных кредитных организаций».
}

12 [1976] ECR 4905. Официальный сайт права EC: <http://eur-lex. europa.eu/LexUriServ/LexUriServ.do?uri=CELEX:61986CJ0218:E $\mathrm{N}: \mathrm{HTML}>$. положений Брюссельской конвенции 1968 г. $^{13}$, присутствие филиала или представительства на территории того или иного государства может признаваться даже без официальной регистрации. В ст. 5 Брюссельской конвенции закреплено право лиц, домицилированных в договаривающихся государствах, выступать ответчиками в другом договаривающемся государстве. В частности, в соответствии с п. 5 ст. 5 Брюссельской конвенции споры о филиалах, представительствах и других учреждениях рассматриваются в судах по месту нахождения этих учреждений. Суд указал, что филиал или представительство считаются существующим даже в том случае, если юридическое лицо не имеет собственного юридически оформленного подразделения на территории иностранного государства, но, тем не менее, ведет деятельность на данной территории через независимую компанию со сходным наименованием, которая заключает сделки от своего имени и фактически выступает в качестве подразделения этого лица.

Как видим, в вопросе о том, как следует определять место нахождения юридического лица, судебная практика Европейского Союза применила неформальное толкование. В соответствии с позициями, изложенными в деле SAR Schotte GmbH v. Parfums Rothschield, место нахождения организации определяется не только местом ее официальной регистрации. Если организация осуществляет свою деятельность под сходным с головной организацией наименованием, и, таким образом, фактически выступает в качестве подразделения такой организации и может существовать независимо от акта органа государственной власти - государственной регистрации, местом нахождения такой организации следует признать место осуществления деятельности. Указанный принцип также прослеживается в отношении кредитных организаций в положениях Директивы 2013/36/EU ${ }^{14}$, установившей, что банки Европейского Союза могут осуществлять банковскую деятельность без получения соответствующего разрешения от органов национальных государств.

\footnotetext{
${ }^{13}$ Брюссельская конвенция по вопросам юрисдикции и принудительного исполнения судебных решений в отношении гражданских и коммерческих споров (Заключена в Брюсселе 27 сентября 1968 г.). В настоящее время заменена Регламентом ЕС Брюссель I bis.

${ }^{14}$ Directive 2013/36/EU of the European Parliament and of the Council of 26 June 2013 on access to the activity of credit institutions and the prudential supervision of credit institutions and investment firms, amending Directive 2002/87/EC and repealing Directives 2006/48/EC and 2006/49/EC. Официальный сайт законодательства ЕC: <http:// old.eur-lex.europa.eu/LexUriServ/LexUriServ.do?uri=OJ:L:2013:17 6:0338:0436:EN:PDF>.
} 
Следует заметить, что в 2012 г. Президиум Высшего арбитражного суда РФ (далее - «ВАС РФ») применил подход, аналогичный делу SAR Schotte GmbH v. Parfums Rothschield ${ }^{15}$. Судом был рассмотрен иск из договора вклада, предъявленный российским лицом к латвийскому банку. Несмотря на то, что договор был заключен напрямую между банком и российским лицом, преддоговорной работой занималось аффилированное с банком третье лицо, зарегистрированное в качестве представительства иной организации на территории России. Данных обстоятельств оказалось достаточно, чтобы суд пришел к выводу о наличии представительства банка и о фактическом оказании услуг от его имени на территории России, несмотря на то, что банк представительство напрямую не учреждал ${ }^{16}$.

Выводы ВАС РФ имеют особое значение в свете развития инновационных банковских услуг. Широкое распространение интернет-банкинга, в том числе возможностей торговли на иностранных валютных рынках через интернет, предоставляют практически неограниченные возможности для иностранных банков продвигать и оказывать услуги по принятию вкладов от российских лиц, ведению их счетов, предоставлению краткосрочных займов, осуществлению обменных операций без присутствия на территории РФ. В свете недавних выводов ВАС РФ такая деятельность может быть квалифицирована в качестве деятельности по оказанию услуг на территории РФ и иметь соответствующие правовые последствия, в том числе в определенных случаях привести к ответственности за нарушение императивных норм законодательства РФ. Тем не менее, остается открытым вопрос о том, какие практические последствия будет иметь возложение ответственности на организацию (банк), не имеющую присутствия на территории РФ $\Phi^{17}$.

\footnotetext{
${ }^{15}$ Постановление Президиума ВАС РФ от 24 мая 2012 г. № 16404/11
} по делу № A40-21127/11-98-184.

${ }^{16}$ В данном деле интересна также аргументация суда, касающаяся наличия тесной связи отношений по вкладу с территорией Латвийской Республики. Так, суд указал, что, поскольку договоры вклада заключались через материнский офис банка в Риге, исполнение по договору осуществлялось в пределах Латвийской Республики, а денежные средства находятся на депозитном счете в Латвии - указанные обстоятельства демонстрируют тесную связь с территорией Латвийской Республики.

${ }^{17}$ Не исключено, что российские суды сочтут возможным обращать взыскание по искам российских кредиторов к иностранным банкам на средства, расположенные на корреспондентских счетах иностранных банков в России. Подобная тенденция просматривается в одном из дел, рассматриваемых в московских судах: cм., напр., аргументацию конкурсного управляющего в деле о несостоятельности ООО «Витас Банк» (постановление Девятого

\section{Международные банки}

Государства, участвуя в международных организациях, играют двоякую роль в отношениях, связанных с международными займами. С одной стороны, в лице таких межправительственных организаций, как, к примеру, МВФ и МБРР, государства определяют взаимные обязанности, связанные с регулированием отношений на международном финансовом рынке. С другой стороны, государства содействуют развитию наименее развитых государств, участвуя в инвестиционных проектах последних. В данном случае наиболее распространенной формой сотрудничества является учреждение международных банков и фондов. Международные банки - особые субъекты как международного, так и национального права, создаваемые на основе межгосударственных соглашений.

Правовой статус международных банков развития определяется учредительными документами. Обычно к таким документам относятся межгосударственные соглашения об учреждении, уставы и соглашения между соответствующим банком и государством, в котором расположена штаб-квартира банка ${ }^{18}$. Международные банки пользуются особыми привилегиями на территории иностранных государств. Так, например, выплаты, производящиеся по договорам международного займа с такими банками, освобождаются от налогообложения на территории государств - участников банка. Следствием этого является другая особенность международных банков - процентные ставки по предоставляемым кредитам таких банков, как правило, ниже рыночных ${ }^{19}$. Подобные исключения из общего право-

апелляционного арбитражного суда от 2 декабря 2013 г. № 09 АП-33772/2013 по делу № А40-93565/12). На момент выпуска настоящей статьи, однако, рассмотрение иска сосредоточено на процессуальных вопросах, поэтому нельзя безусловно утверждать о наличии подобной тенденции.

${ }^{18}$ К примеру, Банк для международных расчетов (далее - «БМР») был учрежден и в настоящее время действует на основании ряда межправительственных соглашений, среди которых Гаагская конвенция в отношении БМР от 20 января 1930 г., Устав БМР от 20 января 1930 г., Статут БМР от 20 января 1930 г., Брюссельский протокол об иммунитете БМР от 30 июля 1936 г., Соглашение между Федеральным советом Швейцарии и БМР об определении правового статуса БМР от 10 февраля 1987 г., Соглашение принимающего государства между БМР и Правительством КНР об учреждении и статусе представительства БМР в Гонконге от 11 мая 1998 г., а также Соглашение принимающего государства между БМР и Мексикой об учреждении и статусе Представительства БМР в Мексике от 5 ноября 2001 г.

${ }^{19}$ Silvestre M.R. International Financial Institutions and Claims of Private Parties: Immunity Obliges // The World Bank Legal Review. 2011. P. 96. 
DOI: $10.7256 / 1811-9018.2014 .8 .12742$

При цитировании этой статьи сноска на доі обязательна

\section{Право и политика $8(176) \cdot 2014$}

вого режима государства устанавливают напрямую в международных договорах, учреждающих соответствующие банки

Среди многочисленных международных банков развития можно выделить такие банки, как Азиатский банк развития, Африканский банк развития, Евразийский банк развития, Европейский банк реконструкции и развития (далее - ЕБРР), Европейский инвестиционный банк, Исламский банк развития, Межамериканский банк развития, Международный банк реконструкции и развития (далее - МБРР $)^{20}$. Последний осуществляет наиболее активную деятельность, поскольку, во-первых, является, наравне с МВФ, одной из первых международных финансовых организаций и, во-вторых, имеет 188 государств-участников. РФ активно сотрудничает с МБРР: в Законе о бюджете на 2013 г., к примеру, было предусмотрено привлечение кредитов (займов) по 19 проектам, все из которых осуществлялись с участием МБРР21.

МБРР был учрежден в 1944 г. в целях реконструкции и развития Европы в период после Второй мировой войны ${ }^{22}$. МБРР действует на основании Статей соглашения о МБРР 1944 г. (далее - Статьи соглашения МБРР), которые вступили в силу 27 декабря 1945 г. Статьи соглашения МБРР являются международным договором, содержащим отдельные положения, касающиеся целей, участников, капитала, управления, статуса, иммунитета и привилегий МБРР, а также основных сделок, осуществляемых МБРР - займов и гарантий. Государства - участники МБРР являются его акционерами. Особенность правового положения государств - участников МБРР, состоит в том, что они не могут обременять принадлежащие им доли в МБРР и каким-либо иным образом распоряжаться ими, за

\footnotetext{
${ }^{20}$ Официальный сайт Азиатского банка развития: <http://www.adb. org>; официальный сайт Африканского банка развития: $<\mathrm{http}: / /$ www.afdb.org>; официальный сайт Евразийского банка развития: $<\mathrm{http}$ ://www.eabr.org $>$; официальный сайт Европейского банка реконструкции и развития: <http://www.ebrd.com >; официальный сайт Европейского инвестиционного банка: http://www.eib. org; официальный сайт Исламского банка развития: <http://www. isdb.org>; официальный сайт Межамериканского банка развития: $<\mathrm{http}$ //www.iadb.org>; Официальный сайт Международного банка реконструкции и развития: <http://web.worldbank.org> .

${ }^{21}$ Приложение 39 «Программа государственных внешних заимствований РФ на 2013 год» к Федеральному закону «О федеральном бюджете на 2013 год и на плановый период 2014 и 2015 годов».

22 Proceedings and Documents of the United Nations Monetary and Financial Conference. Bretton Woods, New Hampshire. Vol. 1. 1944. P. viii.
}

исключением случаев, когда такие доли передаются в пользу МБРР (разд. 10 ст. 2 Статей соглашения МБРР). Государства-участники могут взаимодействовать с МБРР только через министерство финансов, центральный банк, стабилизационный фонд или иной подобный правительственный орган.

Правовое положение МБРР в определенной степени аналогично положению коммерческих организаций. В соответствии с разд. 2 ст. 7 Статей соглашения МБРР последний вправе заключать сделки, приобретать и распоряжаться недвижимым и движимым имуществом, инициировать судебные разбирательства. Тем не менее, в отличие от обычных юридических лиц, МБРР, как и другие международные организации, пользуется рядом иммунитетов и привилегий, закрепленных напрямую в Статьях соглашения МБРР. К примеру, имущество МБРР не может быть предметом:

- обеспечительных мер против МБРР (однако на имущество МБРР может быть обращено взыскание после вынесения окончательного решения (разд. 3 ст. 7 Статей соглашения МБРР));

- расследования, реквизиции, конфискации, экспроприации или иной формы присвоения на основании акта органа исполнительной или законодательной власти;

- $\quad$ любой формы запрета, постановления, контроля или моратория.

Кроме того, под иммунитетом находятся архивы МБРР, средства связи, а также сотрудники МБРР при исполнении своих должностных обязанностей и, в определенных случаях, не являющиеся гражданами соответствующего государства-участника. Основным преимуществом МБРР (как и других международных банков) по сравнению с простыми коммерческими предприятиями является тот факт, что все операции МБРР освобождены от удержаний, связанных с налогами, пошлинами и иными обязательными выплатами (разд. 9 стат. 7 Статей соглашения МБРР). Именно это позволяет МБРР поддерживать низкие процентные ставки по предоставляемым займам и пользоваться популярностью среди участников рынка. МБРР вправе осуществлять три вида операций: предоставлять займы, выступать со-кредитором в синдицированных займах, а также выступать гарантом по займам государствучастников (разд. 4 ст. 3 Статей соглашения МБРР). Заёмщиками могут выступать государства-участники, их публично-правовые образования, а также коммерческие (промышленные, сельскохозяйственные) предприятия, расположенные на территории государств - участников. 
Указанные сделки осуществляются МБРР с соблюдением определенных условий ${ }^{23}$ :

- $\quad$ займы и гарантии МБРР, за исключением особых случаев, предоставляются в целях финансирования специальных проектов реконструкции и развития;

- $\quad$ займы коммерческим предприятиям государствучастников могут предоставляться только с одновременным обеспечением в виде гарантии, предоставляемой соответствующим государствомучастником;

- $\quad$ займы предоставляются только в том случае, если у заёмщика нет иной возможности получить заём в сложившихся рыночных обстоятельствах;

- $\quad$ заём подлежит одобрению внутренним комитетом МБРР, в который входит представитель государства-участника;

- $\quad$ заём предоставляется при условии, что процентные ставки и другие выплаты, связанные с займом, а также сроки таких выплат, являются разумными с учетом целей займа;

- $\quad$ прежде чем получить заём, заёмщик должен продемонстрировать свою платежеспособность в долгосрочной перспективе (а МБРР убедиться в этом); при этом МБРР в своей оценке должен руководствоваться как интересами государстваучастника, которому предоставляется заём, так и интересами всех государств-участников;

- если МБРР выдает гарантию по займу, предоставляемому государству участнику, то МБРР должен иметь достаточную компенсацию по такой гарантии.

Помимо финансовых услуг, указанных выше, МБРР предоставляет услуги по разработке стратегий и координации развития и образовательные услуги, финансирует риски, предоставляет гарантии ${ }^{24}$. Последние МБРР выдает преимущественно в связи с финансированием реформ. Так, например, в 2011 г. под гарантию МБРР Сербия привлекла около 400 миллионов долларов США для проведения структурных реформ внутри страны, для реструктуризации государственного долга ${ }^{25}$. МБРР

\footnotetext{
${ }^{23}$ Исключением из нижеследующих условий являются лишь займы, предоставляемые Международной финансовой корпорации (раздел 6 ст. 3 Статей соглашения МБРР) - аналог так называемых «корпоративных займов».

${ }^{24}$ Официальный сайт МБРР: <http://web.worldbank.org>.

${ }^{25}$ Accessing New Financial Markets and Improving Borrowing Terms in Serbia // Treasury. The World Bank. Официальный сайт МБРР: $<$ http://treasury.worldbank.org/web/documents/Serbia_PBGuaranteeJuly2013.pdf $>$. Привлечение заёмных средств на рынках капи-
}

также выступает со-кредитором: в 2013 г. Мексике был предоставлен заём для внедрения энергоэффективных технологий ${ }^{26}$, в котором МБРР выступил кредитором (250 млн. долларов США) совместно с Фондом «Clean Technologies» (50 млн. долларов США) и Глобальным Фондом окружающей среды (7 млн. долларов США), местным правительством, государственным банком. МБРР предоставляет «опционы на кредитные средства» (drawdown options) $)^{27}$. К примеру, в 2009 г. МБРР предоставил Гватемале опцион до 500 млн. долларов США сроком на 24 года под фиксированную ставку в размере $4,77 \%$. Условием использования опциона являлось возникновение стихийных явлений.

Некоторые из международных банков работают только с правительствами и с правительственными органами (например, как было показано выше, взаимодействие между государствами-участниками и МБРР осуществляется только через государственные органы). Однако, тот факт, что сторонами в международном кредитном договоре выступают, с одной стороны, международная организация (международный банк развития), а, с другой стороны, - государство в лице соответствующего правительства или правительственного органа, не всегда придает данному договору статус международного. Напротив, некоторые договоры содержат специальные условия, касающиеся государственного иммунитета, которые вводят ограничение на различные злоупотребления суверенными правами со стороны государства.

Тем не менее, международные организации, как правило, не отказываются от своих привилегий при заключении договоров международного займа. Некоторыми авторами указывается на анахронизм системы, при которой международные финансовые организации сохраняют иммунитет: последний должен быть значительно ограничен или полностью

тала под гарантии МБРР происходит на условиях, значительно отличающихся от рыночных. Так, к примеру, если бы Сербия привлекала кредитные средства на рыночных условиях, то стоимость такого финансирования равнялось бы базовой ставке ЕВРИБОР + Spread на шесть лет в размере 6-8\%. Напротив, с гарантией МБРР Сербии удалось привлечь кредит под ЕВРИБОР + $1 \%$.

${ }^{26}$ Investing in Residential Energy Efficiency Programs in Mexico // Treasury. The World Bank. Официальный сайт МБРР:<http:// treasury.worldbank.org/web/documents/Mexico_Blending_EnergyEfficiencyJuly2013.pdf>.

${ }^{27}$ Catastrophe Deferred Drawdown Option (Cat DDO) // Treasury. The World Bank. Официальный сайт МБРР:<http://treasury.worldbank. org/web/documents/Guatemala_CatRiskDDOJuly2013.pdf>. 
DOI: $10.7256 / 1811-9018.2014 .8 .12742$

При цитировании этой статьи сноска на доі обязательна

\section{Право и политика 8 (176) 2014}

отменен $^{28}$. Другие авторы выступают за сохранение существующего положения ${ }^{29}$.

Некоторые международные банки, в отличие от МБРР, которые сотрудничает главным образом с национальными правительствами, осуществляют операции также и напрямую с частными лицами, например, ЕБРР. Соглашение об учреждении ЕБРР (далее - Соглашение ЕБРР) было подписано 29 мая 1990 г. в Париже и вступило в силу почти на год позже 28 марта 1991 г. ЕБРР был призван навести порядок в период после холодной войны, внедрить демократические принципы и институты, верховенство права, уважение прав и свобод человека, а также заложить основы рыночной экономики в странах Центральной и Восточной Европы. ЕБРР был учрежден специально для финансирования стран Центральной и Восточной Европы, а также Монголии. ЕБРР тесно сотрудничает с другими международными финансовыми организациями - МВФ, МБРР, МФК, МАГИ, ОЭСР, ООН и ее специализированными учреждениями.

Статья 11 Соглашения ЕБРР определяет способы финансирования, используемые этой международной организацией. В частности, предусматривается предоставление займов частным лицам и государственным предприятиям, при этом такие займы могут предоставляться лично ЕБРР или совместно с другими многосторонними организациями, коммерческими банками и другими «заинтересованными» лицами. Соглашением ЕБРР предусматривается три основные формы финансирования: договоры займа (ст. 11.1 (i)); вложение в доли участия (акции), в том числе путем подписки на акции (ст. 11.1 (ii)); предоставление гарантий (ст. 11.1 (iii)). При этом любое финансирование ЕБРР является целевым (ст. 13 (хііi)) $)^{30}$. Размер финансирования, предоставляемый ЕБРР, может составлять от 5 до 255 миллионов евро.

\section{Государства}

Государство может выступать как в качестве должника (заёмщика), так и в качестве кредитора (займодавца) в зависимости от бюджетных потребностей и возможностей. Вопросы, связанные с правовым ста-

${ }^{28}$ Herz S. Rethinking International Financial Institution Immunity // In: International Financial Institutions and International Law. Kluwer Law International, 2010. P. 137-165.

${ }^{29}$ Silvestre M.R. Op. cit. P. 93-131.

${ }^{30}$ В Соглашении ЕБРР особо оговаривается, что ЕБРР не участвует в инвестициях в оборонную, табачную промышленность, определенные алкогольные продукты, а также азартные игры. тусом государства и государственных органов в том или ином государстве, содержатся в специальных законах. В РФ данный вопрос урегулирован Бюджетным Кодексом РФ (далее - «БК РФ»). В соответствии с БК РФ в случаях, когда государство выступает заёмщиком, образуется государственный долг, а если кредитором - внешние долговые требования. Согласно ст. 97 БК РФ к государственному долгу РФ относятся, среди прочего, долговые обязательства РФ перед иностранными государствами, международными финансовыми организациями, иными субъектами международного права, иностранными физическими и юридическими лицами, возникшие в результате государственных заимствований РФ, а также долговые обязательства по государственным гарантиям, предоставленным Российской Федерацией.

Ст. 98 БК РФ содержит перечень принимаемых РФ обязательств. РФ может принимать на себя, в частности, обязательства по:

- $\quad$ кредитам, привлеченным от имени РФ в качестве заёмщика от кредитных организаций, иностранных государств, в том числе по целевым иностранным кредитам (заимствованиям), международных финансовых организаций, иных субъектов международного права, иностранных юридических лиц;

- $\quad$ государственным ценным бумагам, выпущенным от имени РФ;

- $\quad$ государственным гарантиям РФ.

Порядок предоставления государственных гарантий РФ установлен Правительством РФ ${ }^{31}$. Особенностями государственных гарантий служит то обстоятельство, что они предоставляются только в ограниченных случаях. Постановление № 803 устанавливает требования к предмету основного обязательства: гарантии выдаются в обеспечение торговых экспортных кредитов, предоставляемых в отношении определенной промышленной продукции ${ }^{32}$. Российский экспортер, иностранный импортер, банк-нерезидент или иностранное государство может получить гарантию РФ по синдицированному кредиту, предоставляемому такому лицу в связи с экспортом промышленной продукции с территории РФ на территорию иностранных государств (п. 9 Постановления № 803). Государственная гарантия выдается не всем банкам, а лишь одному, который впоследствии и будет иметь право на предъявление

\footnotetext{
${ }^{31}$ Постановление Правительства РФ от 1 ноября 2008 г. № 803 «Об утверждении Правил предоставления государственных гарантий РФ» (далее - Постановление № 803).

${ }_{32}$ Распоряжение Правительства РФ от 21 сентября 2004 г. № 1222-р «Об утверждении Перечня промышленной продукции».
} 
платежного требования по государственной гарантии и получение денежных средств ${ }^{33}$.

БК РФ выделяет также отдельную группу государственных внешних заимствований, под которыми понимаются государственные займы, осуществляемые путем выпуска государственных ценных бумаг от имени РФ, и кредиты, привлекаемые от кредитных организаций, иностранных государств, включая целевые иностранные кредиты (заимствования), международных финансовых организаций, иных субъектов международного права, иностранных юридических лиц, по которым возникают долговые обязательства РФ, выраженные в иностранной валюте (ст. 103.4 БК РФ). Решение о предоставлении займа принимается Правительством РФ или Министерством финансов РФ.

Необходимо отметить особый правовой режим договоров, заключаемых между Правительством РФ и иностранными кредиторами в связи с государственными внешними заимствованиями. Указанные договоры должны быть ратифицированы, если: во-первых, они не включены в соответствующие государственные программы законом о бюджете и (или) привлекаемые по таким займам средства превышают сумму в 10 миллионов долларов США (по гарантиям - 50 миллионов долларов США); во-вторых, если исполнение по таким договорам превышает верхний предел государственного долга, предусмотренный законом о бюджете: в-третьих, по другим основаниям, предусмотренным законодательством РФ. Исключением из указанного правила является, в частности, случай, когда Правительство РФ или Министерство Финансов РФ осуществляет внешние заимствования для того, чтобы снизить расходы по обслуживанию государственного долга (выплате процентов по привлеченным займам), но в рамках верхнего предела государственного долга РФ.

С другой стороны, РФ может выступать в качестве кредитора, приобретая так называемые внешние долговые требования. В соответствии со ст. 122.1 БК РФ под такими требованиями понимаются финансовые обязательства иностранных государств и (или) иностранных юридических лиц перед Российской Федерацией в качестве кредитора, включая долговые требования, возникшие в связи с предоставлением банком - агентом Правительства РФ государственных экспортных кредитов иностранным заёмщикам или их банкам-кредиторам. Как видим, в БК РФ акцент сделан на поддержку государством экспортно-импортных

\footnotetext{
${ }^{33}$ По смыслу Постановления № 803 такой банк именуется «уполномоченным банком синдиката банков-кредиторов».
}

операций путем предоставления соответствующих кредитов. Тем не менее, государственные кредиты могут быть использованы также и в политических целях: заёмные отношения спасают страны от дефолтов, а иногда и политических кризисов ${ }^{34}$.

БК РФ различает две формы кредита: государственный финансовый кредит и государственный экспортный кредит. Государственный финансовый кредит представляет собой форму бюджетного кредита, при которой РФ предоставляет денежные средства иностранному заёмщику в объеме и на условиях, предусмотренных соответствующим соглашением между Правительством РФ и правительством иностранного государства. Государственный экспортный кредит представляет собой форму бюджетного кредита, при которой за счет бюджетных средств осуществляется оплата товаров и услуг, экспортируемых в пользу иностранного заёмщика - импортера товаров и услуг, в объеме и на условиях, предусмотренных соответствующим соглашением между Правительством РФ и правительством иностранного государства или соответствующим договором между банком - агентом Правительства РФ и иностранным заёмщиком - импортером товаров и услуг или его банком-кредитором, при наличии государственной гарантии иностранного государства по возврату этого кредита, платежи в погашение и обслуживание которого осуществляются в пользу РФ. Кроме того, БК РФ предусматривает возможность уступки прав по внешним долговым требованиям.

Специфической формой участия государства в правоотношениях, связанных с международным договором займа, является страхование. К примеру, во Франции страхование кредитов занимается COFACE - Французская страховая компания для внешней торговли, целью которой является гарантирование коммерческих или профессиональных требований к иностранному государству, или иностранной государственной организации, или к приравненному к ним государственному покупателю, а иногда и к частным торговым и промышленным иностранным предприятиям ${ }^{35}$. Российским аналогом COFACE является созданное в 2011 г. Российское агентство по страхованию экспортных кредитов и инвестиций (ЭКСАР), предшественником которого было Российское экс-

\footnotetext{
${ }^{34}$ Примечательно в этом отношении решение Правительства РФ предоставить государственный кредит в форме облигаций Правительству Украины в связи с политическим кризисом конца 2013 - начала 2014 г.

${ }^{35}$ Воронина Е.И. Обеспечение исполнения кредитного договора по праву Франции. Дисс. ... канд. юрид. наук. М., 2002. С. 12.
} 
DOI: $10.7256 / 1811-9018.2014 .8 .12742$

При цитировании этой статьи сноска на доі обязательна

\section{Право и политика $8(176) \cdot 2014$}

портно-импортное страховое сообщество. Функции по организации экспортных кредитов и инвестиций возложены законом на государственную корпорацию «Банк развития и внешнеэкономической деятельности (Внешэкономбанк)», однако они осуществляются через ЭКСАР, при этом задача Внешэкономбанка предоставлять для этих целей финансовую поддержку ЭКСАР ${ }^{36}$. Правила страхования экспортных кредитов и инвестиций устанавливаются на уровне нормативных актов Правительства $Р \Phi^{37}$.

В некоторых странах существуют отдельные агентства по управлению государственным долгом. Так, например, в Англии существует Орган по управлению долгом Соединенного королевства (UK Debt Management Office), подчиненный Казначейству Её Величества и учрежденный в 1998 г. ${ }^{38}$. Орган по управлению долгом Англии использует ресурсы Национального фонда займов (National loans fund) - аналога российского Фонда национального благосостояния. Основная функция Органа по управлению долгом Англии - эмиссия государственных ценных бумаг, обеспеченных золотом (guilts). Аналогичный орган был учрежден в 1988 г. в Новой Зеландии (New Zealand Debt Management Office), основная функция которого, также, как и у английского ведомства - эмиссия государственных ценных бумаг ${ }^{39}$. В РФ аналогичную функцию выполняет Министерство финансов РФ $\Phi^{40}$.

\section{Коммерческие организации}

Коммерческие организации выступают, главным образом, на стороне заёмщиков и третьих лиц. Заёмщиком в договоре международного займа может выступать любое дееспособное лицо. Тем не менее, на практике в договоре международного займа заёмщиками выступают крупные коммерческие пред-

\footnotetext{
${ }^{36}$ Пункт 6(е) Меморандума о финансовой политике государственной корпорации «Банк развития и внешнеэкономической деятельности (Внешэкономбанк)», утвержденного распоряжением Правительства РФ от 27 июля 2007 г. № 1007-р.

${ }^{37}$ Постановление Правительства РФ от 22 ноября 2011 г. № 964 «О порядке осуществления деятельности по страхованию экспортных кредитов и инвестиций от предпринимательских и политических рисков».

${ }^{38}$ United Kingdom Debt Management Office. Executive Agency Framework Document. Official Web Site: $<$ http://www.dmo.gov.uk/>.

${ }^{39}$ New Zealand Debt Management Office Web Site: $<$ http://www. nzdmo.govt.nz $>$.

${ }^{40}$ П. 5.3.16 Постановления Правительства РФ от 30 июня 2004 г. № 329 «О Министерстве финансов РФ».
}

приятия ${ }^{41}$, поскольку только такие организации могут позволить себе принять значительные обязательства, содержащиеся в соответствующих договорах, и предоставить необходимое обеспечение под крупный международный заём. Иногда заёмщик выступает головной организацией группы компаний, участнику или некоторым участникам которых будут предоставлены последующие займы ${ }^{42}$. В таких случаях исполнение обязательств заёмщика, скорее всего, будет обеспечено его дочерними предприятиями, например, путем предоставления поручительства, залога долей (акций), движимого имущества или ипотеки.

Отдельная категория субъектов в правоотношениях, связанных с договором международного займа - третьи лица. Третьи лица не являются субъектами собственно заёмного обязательства: они выступают поручителями, залогодателями, гарантами, либо оказывают посреднические услуги. В некоторых правоотношениях роль третьего лица может принимать на себя заёмщик: к примеру, в случае если в обеспечение кредита предоставляется имущество, принадлежащее заёмщику, последний будет также выступать залогодателем по обеспечительному обязательству. С другой стороны, займодавец в подавляющем большинстве случаев в отношениях с третьими лицами будет выступать кредитором: залогодержателем в договоре залога, бенефициаром в банковской гарантии, кредитором в поручительстве и проч.

Третьи лица в правоотношениях, связанных с договором международного займа - это, главным образом, лица, предоставляющие обеспечение. В качестве обеспечения по международному займу широко используется поручительство. Поручителем может выступить как юридическое лицо (в том числе кредитная организация), физическое лицо, так и правительственный орган. Иногда поручителями выступают лица, принадлежащие к одной группе компаний - в подобном случае может иметь место нисходящее (down-stream), восходящее (upstream) и горизонтальное (cross-stream) поручительство. В нисходящем поручительстве поручителем выступает материнское общество, а должником - дочернее, в то время как в восходящем поручительстве - наоборот: дочернее общество выступает поручителем по обяза-

\footnotetext{
${ }^{41}$ Wood P.R. International Loans, Bonds and Securities Regulation. London: Sweet\&Maxwell, 1995. P. 3; Шамраев А.В. Правовое регулирование международных банковских сделок и сделок на международном финансовых рынках: научное издание / А.В. Шамраев. М.: КНОРУС, ЦИПСиР, 2010. С. 12.

${ }^{42} \mathrm{CM}$., напр.: Постановление Девятого арбитражного апелляционного суда от 24 декабря 2013 г. № 09АП-42306/2013-ГК.
} 
тельствам материнского общества. В горизонтальном поручительстве поручителем и должникам выступают дочерние общества единого материнского общества. Проведение различия между нисходящим, восходящим и горизонтальным поручительством позволяет продемонстрировать основания, которые могут послужить поводом для оспаривания сделок из поручительства. В данном случае речь идет о так называемой корпоративной выгоде (corporate benefit) ${ }^{43}$.

Иная форма участия третьих лиц в правоотношениях, связанных с договором международного займа - посредничество. Несмотря на то, что посредничество не находит широкого распространения в двусторонних договорах международного займа, в практике договоров синдицированного займа посредничество используется достаточно часто и может приобретать различные формы. Наиболее распространенными формами посредничества являются агентские отношения. Агент выполняет функции представительства кредиторов по широкому кругу вопросов, связанных с заёмным обязательством - от получения и работы с поступающей от заёмщика и кредиторов корреспонденции до осуществления определенных прав займодавцев. В случае с обеспечением стороны могут также оговорить отдельную кандидатуру - агента по обеспечению (управляющего обеспечением). Управляющий обеспечением - институт, широко используемый в практике международного заимствования и нашедший свое воплощение в новой редакции ст. 356 ГК РФ, которая предусматривает возможность заключения договора управления залогом. Своеобразно институт управляющего обеспечением используется в отношениях, связанных с безакцептным списанием средств по договору банковского счета - «способе обеспечения», широко используемом в практике международных займов с участием иностранных банков: в данном случае управляющим обеспечением именуют банк, в котором открыты счета должника-заёмщика ${ }^{44}$.

Важным звеном в правоотношениях, связанных с договором международного займа, являются юридические советники. В их обязанности может входить не только предоставление консультаций и выдача заклю-

\footnotetext{
${ }^{43}$ См.: Попытка ВАС РФ прояснить понятие корпоративной выгоды // Обзор изменений в законодательстве компании. М.: ЗАО «Дентонс Юроп». Август, 2013.

44 Договором о безакцептном списании денежных средств (direct debit agreement) предусматривается право займодавца списывать поступающие на определенный счет заёмщика денежные средства на основании заранее данного акцепта. См.: П. 2.9.1 Положения ЦБ РФ о правилах осуществления перевода денежных средств от 19 июня 2012 г. № 383-П.
}

чений применительно к правоотношениям, в которые вступают заёмщик и займодавец (на практике и с той и с другой стороны будет стоять целый отряд юристов), но также и осуществление определенных действий, связанных с заключением договора. К примеру, юридический советник может выполнять роль лица, уполномоченного на совершение действий, необходимых для заключения договора «между отсутствующими» сторонами. В подчиненных английскому праву договорах широко распространена практика «удаленного заключения соглашений»: юридический консультант отправляет по электронной почте каждой стороне окончательно согласованную форму соглашения. Сторона распечатывает необходимое количество экземпляров и подписывает их и затем отправляет по электронной почте консультанту, который по получении соответствующих документов от всех сторон формирует копию подписанного соглашения в качестве единого документа. В последствии оригиналы подписанных страниц высылаются юридическому консультанту, который «доводит» подписание до логического завершения, рассылая оригиналы договоров сторонам. Несмотря на простоту и удобство такого порядка заключения договора, в договорной практике по английскому праву не обошлось без злоупотреблений со стороны уполномоченного лица-консультанта ${ }^{45}$.

\section{Библиография:}

1. Трубецкой Е.Н. Энциклопедия права. М.: Юридический институт (Санкт-Петербург), 1998.

2. Федеральный закон РФ от 8 февраля 1998 г. № 14-Ф3 «Об обществах с ограниченной ответственностью».

3. Федеральный закон РФ от 10 декабря 2003 г. № 173-Ф3 «О валютном регулировании и валютном контроле».

4. Инструкция Центрального Банка РФ от 4 июня 2012 г. № 138-И «О порядке представления резидентами и нерезидентами уполномоченным банкам документов и информации, связанных с проведением валютных операций, порядке оформления паспортов сделок, а также порядке учета уполномоченными банками валютных операций и контроля за их проведением».

5. Бюджетный кодекс Российской Федерации.

\footnotetext{
${ }^{45}$ См., например, Дело «Меркюри»: [2008] EWHC 2721 (Admin). Сайт в интернете: <http://www.bailii.org/ew/cases/EWHC/Ad$\min / 2008 / 2721 . h t m l>$.
} 


\section{Право и политика $8(176) \cdot 2014$}

6. Principles on the operation of close-out netting provisions // International Institute for the Unification of Private Law (UNIDROIT). Rome, 2013.

7. Путилин В.И. Технологии международного синдицированного кредитования // Международные банковские операции. 2012. № 4.

8. Постановление Федерального арбитражного суда Московского округа от 06 июля 2004 г. по делу № КГ-А40/3926-04.

9. Постановление Седьмого арбитражного апелляционного суда от 13 августа 2013 г. по делу № A45-29905/2012.

10. Кыров А.А. Правовые основания заключения кредитного договора с иностранным юридическим лицом // Судебно-арбитражная практика Московского региона. Вопросы правоприменения. 2008. № 5.

11. E. Cerutti, G. Dell-Ariccia, M. Soledad Marinez Reia. How Banks Go Abroad: Branches or Subsidiaries? // Policy Research Working Papers. World Bank. 2005. World Bank official website: .

12. ПриказЦентрального банкаРФ от 7 октября 1997 г.№02437 «О порядке открытия и деятельности в РФ представительств иностранных кредитных организаций».

13. Брюссельская конвенция по вопросам юрисдикции и принудительного исполнения судебных решений в отношении гражданских и коммерческих споров (Заключена в Брюсселе 27 сентября 1968 г.).

14. Directive 2013/36/EU of the European Parliament and of the Council of 26 June 2013 on access to the activity of credit institutions and the prudential supervision of credit institutions and investment firms, amending Directive 2002/87/EC and repealing Directives 2006/48/EC and 2006/49/EC.

15. Постановление Президиума ВАС РФ от 24 мая 2012 г. № 16404/11 по делу № A40-21127/11-98-184.

16. Постановление Девятого апелляционного арбитражного суда от 2 декабря 2013 г. № 09 АП33772/2013 по делу № A40-93565/12.

17. Silvestre M.R. International Financial Institutions and Claims of Private Parties: Immunity Obliges // The World Bank Legal Review. 2011.

18. Федеральный закон «О федеральном бюджете на 2013 год и на плановый период 2014 и 2015 годов».

19. Proceedings and Documents of the United Nations Monetary and Financial Conference. Bretton Woods, New Hampshire. Vol. 1. 1944.

20. Accessing New Financial Markets and Improving Borrowing Terms in Serbia // Treasury. The World Bank. Официальный сайт МБРР: .
21. Investing in Residential Energy Efficiency Programs in Mexico // Treasury. The World Bank. Официальный сайт МБРР..

22. Catastrophe Deferred Drawdown Option (Cat DDO) // Treasury. The World Bank. Официальный сайт МБРР.

23. Herz S. Rethinking International Financial Institution Immunity // In: International Financial Institutions and International Law. Kluwer Law International, 2010.

24. Постановление Правительства РФ от 1 ноября 2008 г. № 803 «Об утверждении Правил предоставления государственных гарантий РФ».

25. Распоряжение Правительства РФ от 21 сентября 2004 г. № 1222-р «Об утверждении Перечня промышленной продукции».

26. Воронина Е.И. Обеспечение исполнения кредитного договора по праву Франции. Дисс. ... канд. юрид. наук. М., 2002. С. 12.

27. Меморандум о финансовой политике государственной корпорации «Банк развития и внешнеэкономической деятельности (Внешэкономбанк)», утвержденный распоряжением Правительства РФ от 27 июля 2007 г. № 1007-p.

28. Постановление Правительства РФ от 22 ноября 2011 г. № 964 «О порядке осуществления деятельности по страхованию экспортных кредитов и инвестиций от предпринимательских и политических рисков».

29. United Kingdom Debt Management Office. Executive Agency Framework Document. Official Web Site: .

30. Постановление Правительства РФ от 30 июня 2004 г. № 329 «О Министерстве финансов РФ».

31. Wood P.R. International Loans, Bonds and Securities Regulation. London: Sweet\&Maxwell, 1995.

32. Шамраев А.В. Правовое регулирование международных банковских сделок и сделок на международном финансовых рынках: научное издание / А.В. Шамраев. М.: КНОРУС, ЦИПСиР, 2010.

33. Постановление Девятого арбитражного апелляционного суда от 24 декабря 2013 г. № 09АП42306/2013-ГК.

34. Попытка ВАС РФ прояснить понятие корпоративной выгоды // Обзор изменений в законодательстве компании. М.: ЗАО «Дентонс Юроп». Август, 2013.

35. Положение ЦБ РФ о правилах осуществления перевода денежных средств от 19 июня 2012 г. № 383-П.

36. Ерпылева Н.Ю. Международное гражданско-процессуальное право: понятие, предмет и система // NB: Международное право. - 2013. - № 4. - C.16160. DOI: $10.7256 / 2306-9899.2013 .4 .10362$. URL: http://e-notabene.ru/wl/article_10362.html 
37. Ерпылева Н.Ю. Международный коммерческий арбитраж: правовые основы функционирования // NB: Международное право. - 2013. - № 1. - C.1-74. DOI: 10.7256/2306-9899.2013.1.545. URL: http://enotabene.ru/wl/article_545.html

38. Ерпылева Н.Ю.. Международное чековое право и российское законодательство: основные категории и механизмы регулирования чековых отношений // Международное право и международные организации / International Law and International Organizations. - 2014. - № 1. - C. 104-107. DOI: 10.7256/2226-6305.2014.1.11578

39. Ерпылева Н.Ю., Максимов Д.М.. Правовое регулирование международных комбинированных перевозок грузов, пассажиров и багажа // Международное право и международные организации / International Law and International Organizations. - 2013. - № 4. - C. 104-107. DOI: 10.7256/2226-6305.2013.4.10356

40. Ерпылева Н.Ю., Клевченкова М.Н.. Унификация норм о международной судебной юрисдикции в международном процессуальном праве // Международное право и международные организации / International Law and International Organizations. - 2013. - № 3. - C. 104-107. DOI: 10.7256/2226-6305.2013.3.8984

41. Н.Ю. Ерпылева, У.Э. Батлер. Производство по делам с участием иностранных лиц в международном процессуальном праве России и Украины: современное правовое регулирование // Международное право и международные организации / International Law and International Organizations. - 2013. - № 1. C. 104-107. DOI: $10.7256 / 2226-6305.2013 .01 .3$

42. Н.Ю. Ерпылева, Д.М. Максимов. Правовой статус межправительственной организации по международным железнодорожным перевозкам // Международное право и международные организации / International Law and International Organizations. - 2012. - № 4. - C. 104-107.

43. Н. Ю. Ерпылева, Д. М. Максимов. Правовое регулирование международных железнодорожных перевозок // Международное право и международные организации / International Law and International Organizations. - 2012. - № 3. - C. 104-107.

44. Н. Ю. Ерпылева, И. В. Гетьман-Павлова. Кодификация международного частного права в Республике Грузия // Международное право и международные организации / International Law and International Organizations. - 2012. - № 2. - C. 104-107.

\section{References (transliteration):}

1. Trubetskoi E.N. Entsiklopediya prava. M.: Yuridicheskii institut (Sankt-Peterburg), 1998.

2. Putilin V.I. Tekhnologii mezhdunarodnogo sinditsirovannogo kreditovaniya // Mezhdunarodnye bankovskie operatsii. 2012. № 4.

3. Kyrov A.A. Pravovye osnovaniya zaklyucheniya kreditnogo dogovora s inostrannym yuridicheskim litsom // Sudebno-arbitrazhnaya praktika Moskovskogo regiona. Voprosy pravoprimeneniya. 2008. № 5.

4. E. Cerutti, G. Dell-Ariccia, M. Soledad Marinez Reia. How Banks Go Abroad: Branches or Subsidiaries? // Policy Research Working Papers. World Bank. 2005. World Bank official website: .

5. Silvestre M.R. International Financial Institutions and Claims of Private Parties: Immunity Obliges // The World Bank Legal Review. 2011.

6. Herz S. Rethinking International Financial Institution Immunity // In: International Financial Institutions and International Law. Kluwer Law International, 2010.

7. Voronina E.I. Obespechenie ispolneniya kreditnogo dogovora po pravu Frantsii. Diss. ... kand. yurid. nauk. M., 2002. S. 12.

8. Wood P.R. International Loans, Bonds and Securities Regulation. London: Sweet\&Maxwell, 1995.

9. Shamraev A.V. Pravovoe regulirovanie mezhdunarodnykh bankovskikh sdelok i sdelok na mezhdunarodnom finansovykh rynkakh: nauchnoe izdanie / A.V. Shamraev. M.: KNORUS, TsIPSiR, 2010.

10. Erpyleva N.Yu. Mezhdunarodnoe grazhdanskoprotsessual'noe pravo: ponyatie, predmet i sistema // NB: Mezhdunarodnoe pravo. - 2013. - № 4. - S.16-160. DOI: 10.7256/2306-9899.2013.4.10362. URL: http://enotabene.ru/wl/article_10362.html

11. Erpyleva N.Yu. Mezhdunarodnyi kommercheskii arbitrazh: pravovye osnovy funktsionirovaniya // NB: Mezhdunarodnoe pravo. - 2013. - № 1. - S.1-74. DOI: 10.7256/2306-9899.2013.1.545. URL: http://e-notabene. $\mathrm{ru} / \mathrm{wl} /$ article_545.html

12. Erpyleva N.Yu.. Mezhdunarodnoe chekovoe pravo i rossiiskoe zakonodatel'stvo: osnovnye kategorii i mekhanizmy regulirovaniya chekovykh otnoshenii // Mezhdunarodnoe pravo i mezhdunarodnye organizatsii / International Law and International Organizations. - 2014. - № 1. - S. 104-107. DOI: 10.7256/22266305.2014.1.11578

13. Erpyleva N.Yu., Maksimov D.M.. Pravovoe regulirovanie mezhdunarodnykh kombinirovannykh perevozok gruzov, passazhirov i bagazha // Mezhdunarodnoe 
DOI: $10.7256 / 1811-9018.2014 .8 .12742$

При цитировании этой статьи сноска на доі обязательна

\section{Право и политика 8 (176) • 2014}

pravo i mezhdunarodnye organizatsii / International Law and International Organizations. - 2013. - № 4. - S. 104-107. DOI: 10.7256/2226-6305.2013.4.10356

14. Erpyleva N.Yu., Klevchenkova M.N.. Unifikatsiya norm o mezhdunarodnoi sudebnoi yurisdiktsii v mezhdunarodnom protsessual'nom prave // Mezhdunarodnoe pravo i mezhdunarodnye organizatsii / International Law and International Organizations. - 2013. - № 3. - S. 104-107. DOI: 10.7256/2226-6305.2013.3.8984

15. N.Yu. Erpyleva, U.E. Batler. Proizvodstvo po delam $\mathrm{s}$ uchastiem inostrannykh lits $\mathrm{v}$ mezhdunarodnom protsessual'nom prave Rossii i Ukrainy: sovremennoe pravovoe regulirovanie // Mezhdunarodnoe pravo i mezhdunarodnye organizatsii / International Law and International Organizations. - 2013. - № 1. S. 104-107. DOI: 10.7256/2226-6305.2013.01.3
16. N.Yu. Erpyleva, D.M. Maksimov. Pravovoi status mezhpravitel'stvennoi organizatsii po mezhdunarodnym zheleznodorozhnym perevozkam // Mezhdunarodnoe pravo i mezhdunarodnye organizatsii / International Law and International Organizations. 2012. - № 4. - S. 104-107.

17. N. Yu. Erpyleva, D. M. Maksimov. Pravovoe regulirovanie mezhdunarodnykh zheleznodorozhnykh perevozok // Mezhdunarodnoe pravo i mezhdunarodnye organizatsii / International Law and International Organizations. - 2012. - № 3. - S. 104-107.

18. N. Yu. Erpyleva, I. V. Get'man-Pavlova. Kodifikatsiya mezhdunarodnogo chastnogo prava v Respublike Gruziya // Mezhdunarodnoe pravo i mezhdunarodnye organizatsii / International Law and International Organizations. - 2012. - № 2. - S. 104-107. 